\title{
A Supramolecular ON-OFF-ON Fluorescence Assay for Selective Recognition of GTP
}

Prakash P. Neelakandan, Mahesh Hariharan and Danaboyina Ramaiah*

* To whom correspondence should be addressed at:

Photosciences and Photonics

Chemical Sciences and Technology Division

Regional Research Laboratory (CSIR)

Trivandrum 695 019, INDIA.

Tel: +914712515362.

Fax: +91 4712490186.

E-mail : rama@csrrltrd.ren.nic.in or d_ramaiah@ rediffmail.com

\section{SUPPLEMENTARY SUPPORTING INFORMATION}

Synthesis, calculation details, processing of biological fluids and Figures S1-S15 showing absorption and fluorescence properties of HPTS in presence and absence of the receptor $\mathbf{1}$ and the complex [1.HPTS] in presence of various nucleotides, nucleosides under different experimental conditions. 
1. General experimental techniques. ${ }^{1} \mathrm{H}$ and ${ }^{13} \mathrm{C}$ NMR were measured on a $300 \mathrm{MHz}$ Bruker advanced DPX spectrometer. The electronic absorption spectra were recorded on a Shimadzu UV-VIS-NIR spectrophotometer. Fluorescence spectra were recorded on a SPEXFluorolog F112X spectrofluorimeter. Quinine sulphate $\left(\Phi_{f}=0.54\right)$ in $0.1 \mathrm{~N} \mathrm{H}_{2} \mathrm{SO}_{4}$ was used as the standard. The quantum yields of fluorescence were calculated using the equation 1 ,

$$
\Phi_{\mathrm{u}}=\frac{\mathrm{A}_{\mathrm{s}} \mathrm{F}_{\mathrm{u}} \mathrm{n}_{\mathrm{u}}^{2}}{\mathrm{~A}_{\mathrm{u}} \mathrm{F}_{\mathrm{s}} n_{\mathrm{s}}^{2}} \Phi_{\mathrm{s}}
$$

where, $A_{s}$ and $A_{u}$ are the absorbance of standard and unknown, respectively. $F_{s}$ and $F_{u}$ are the areas of fluorescence peaks of the standard and unknown and $n_{s}$ and $n_{u}$ are the refractive indices of the solvents used for the standard and unknown, respectively. $\Phi_{s}$ and $\Phi_{u}$ are the fluorescence quantum yields of the standard and unknown compound.

Fluorescence lifetimes were measured using a IBH Picosecond single photon counting system. The fluorescence decay profiles were deconvoluted using IBH data station software V2.1, fitted with monoexponential decay and minimizing the $\chi^{2}$ values of the fit to $1 \pm 0.1$. Cyclic voltammograms were recorded in Bioanalytical Systems Inc., BAS-CV50W cyclic voltammeter. Doubly distilled water was used in all the studies. Petroleum ether used was the fraction with boiling range $60-80{ }^{\circ} \mathrm{C}$. All experiments were carried out at room temperature $(25$ $\pm 1{ }^{\circ} \mathrm{C}$ ), unless otherwise mentioned.

2. Calculation of association constants $\left(\boldsymbol{K}_{\text {ass }}\right)$. 8-hydroxy-1,3,6-pyrene trisulfonate (HPTS), nucleotides and nucleosides (Sigma Aldrich) solution were prepared in distilled water. The binding affinities were calculated using Benesi-Hildebrand equation 2,

$$
\frac{1}{\left(A_{f}-A_{o b}\right)}=\frac{1}{\left(A_{f}-A_{f c}\right)}+\frac{1}{K\left(A_{f}-A_{f c}\right) \text { [Ligand] }}
$$

where, $K$ is the equilibrium constant, $A_{f}$ is the absorbance of free host, $A_{o b}$ is the observed absorbance in the presence of various ligands and $A_{f c}$ is the absorbance at saturation. The linear dependence of $1 /\left(A_{f}-A_{o b}\right)$ on the reciprocal of the ligand concentration indicates the formation of a 1:1 molecular complex between ligand and the host.

3. Processing of blood sample. ${ }^{1}$ Fresh blood samples collected from healthy people were immediately treated with EDTA and centrifuged at $3000 \mathrm{rpm}$ for $5 \mathrm{~min}$ and the supernatant was collected. This supernatant was divided into two portions. One of the portions was subjected to deproteinization by stirring with $20 \%$ trichloroacetic acid followed by centrifugation at $3000 \mathrm{rpm}$ for $5 \mathrm{~min}$ as described in the literature ${ }^{1}$ and used for further studies after diluting 1000 times with water. The other portion was used as such after dilution with water. The $\mathrm{pH}$ of all blood samples used for the experiments was maintained at 7.4.

4. Calculation of change in free energy $\left(\Delta G_{\mathrm{ET}}\right)$ for photoinduced electron transfer. The change in free energy $\left(\Delta G_{\mathrm{ET}}\right)$ for the photoinduced electron transfer reaction was evaluated according to Rehm-Weller equation $3{ }^{2}$

$$
\Delta G_{E T}=E_{o x}-E_{r e d}-E_{0,0}
$$

where, $E_{(0,0)}$ is the singlet excitation energy in $\mathrm{eV}, \mathrm{E}_{\mathrm{ox}}$ is the oxidation potential of the donor and $E_{\text {red }}$ is the reduction potential of the acceptor. 
The oxidation potential of anthracene $(1.9 \mathrm{eV}),{ }^{3}$ reduction potential of viologen $(-0.45$ $\mathrm{eV})^{4}$ and singlet state energy of anthracene $(3.18 \mathrm{eV})$ were used for calculations. The change in free energy value for the electron transfer from the singlet excited state of the anthracene chromophore to the viologen moiety was found to be $-0.77 \mathrm{eV}$, which predicts a facile quenching of the anthracene chromophore fluorescence by the viologen moiety through an electron transfer mechanism.

The oxidation potential of HPTS $(0.42 \mathrm{eV}){ }^{5}$ reduction potential of the viologen moiety $(-0.45 \mathrm{eV})$ and singlet state energy of HPTS $(2.59 \mathrm{eV})$ were used for calculations. The change in free energy value for the electron transfer from the excited state of HPTS to the viologen moiety was found to be $-1.72 \mathrm{eV}$, which predicts a facile quenching of the fluorescence of HPTS by the viologen moiety through an electron transfer mechanism.

\section{Synthesis of the cyclic system 1 and the model compound $2{ }^{6}$}

The synthesis of the cyclic derivative $\mathbf{1}$ was achieved as shown in Scheme 1.

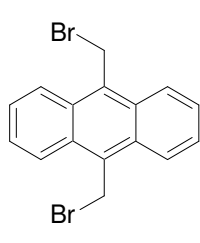

3

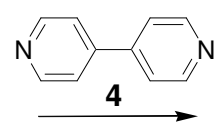

1) $\mathrm{CH}_{3} \mathrm{CN}$

2) $\mathrm{NH}_{4} \mathrm{PF}_{6} / \mathrm{H}_{2} \mathrm{O}$

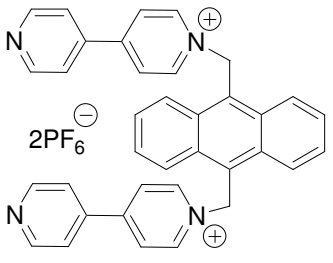

5

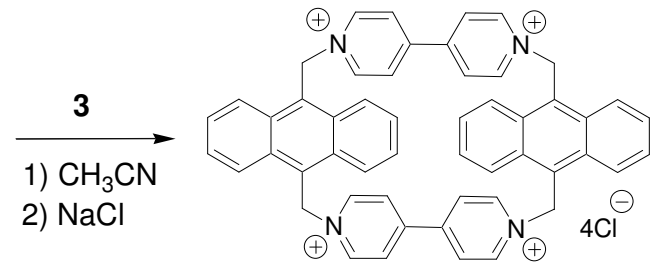

1

Scheme 1

Note: The numbers of the compounds given here correspond to those given in the manuscript.

Preparation of 1,1'-[9,10-anthrylbis(methylene)]bis-4,4'bipyridinium bis(hexafluorophosphate) (5). A solution of 9,10-bis(bromomethyl)-anthracene, 3 (1 g, $2.747 \mathrm{mmol}$ ) in dry $\mathrm{CH}_{3} \mathrm{CN}(20 \mathrm{~mL})$ was added to a solution of 4,4'-bipyridyl, $4(2.143 \mathrm{~g}, 13.735 \mathrm{mmol})$ in dry $\mathrm{CH}_{3} \mathrm{CN}(5 \mathrm{~mL})$ over a period of $30 \mathrm{~min}$ at $25{ }^{\circ} \mathrm{C}$. The reaction mixture was refluxed for 4 $\mathrm{h}$ at $80{ }^{\circ} \mathrm{C}$ and then cooled to room temperature. The precipitated product was filtered, washed with dry $\mathrm{CH}_{3} \mathrm{CN}(3 \mathrm{~mL})$ and dissolved in water $(25 \mathrm{~mL})$. The aqueous solution was washed with $\mathrm{CH}_{2} \mathrm{Cl}_{2}$ thrice, $5 \mathrm{~mL}$ each time, and then water was removed under vacuum to give a solid residue, which was then recrystallized from water. The product was redissolved in hot water, and a saturated aqueous solution of $\mathrm{NH}_{4} \mathrm{PF}_{6}$ was added to yield $1.64 \mathrm{~g}(88 \%)$ of 5, mp $>250{ }^{\circ} \mathrm{C}$, after recrystallization from acetonitrile; ${ }^{1} \mathrm{H} \mathrm{NMR}\left(\mathrm{CD}_{3} \mathrm{COCD}_{3}, 300 \mathrm{MHz}\right) \delta$ $7.40(4 \mathrm{H}, \mathrm{s}), 7.81-7.85(4 \mathrm{H}, \mathrm{m}), 7.98-8.00(4 \mathrm{H}, \mathrm{d}, \mathrm{J}=6.1 \mathrm{~Hz}), 8.59-8.62(4 \mathrm{H}, \mathrm{d}, \mathrm{J}=6.7 \mathrm{~Hz})$, 8.70-8.74 (4H, m), 8.88-8.90 (4H, d, J = 6.1 Hz), 9.21-9.23 $(4 \mathrm{H}, \mathrm{d}, \mathrm{J}=6.7 \mathrm{~Hz}) ;{ }^{13} \mathrm{C} \mathrm{NMR}$ $\left(\mathrm{CD}_{3} \mathrm{COCD}_{3}, 75 \mathrm{MHz}\right) \delta 58.2,114.3,114.5,115.8,116.2,117.7,123.8,127.1,128.7,131.2$, 144.7; HRMS (FAB) $m / z$ Calcd for $\mathrm{C}_{36} \mathrm{H}_{28} \mathrm{~N}_{4} \mathrm{P}_{2} \mathrm{~F}_{12}\left(\mathrm{M}-\mathrm{PF}_{6}\right)$ : 661.5986. Found: 661.5991 $\left(\mathrm{M}-\mathrm{PF}_{6}\right)^{+}$.

Preparation of the cyclic derivative 1. A solution of 9,10-bis(bromomethyl)anthracene, $3(0.3 \mathrm{~g}, 0.8 \mathrm{mmol})$ and $5(1 \mathrm{~g}, 1.2 \mathrm{mmol})$ in dry $\mathrm{CH}_{3} \mathrm{CN}(100 \mathrm{~mL})$ was heated 
under reflux at $80{ }^{\circ} \mathrm{C}$ for $24 \mathrm{~h}$. The reaction mixture was cooled to room temperature to give a precipitate which was filtered and washed with dry $\mathrm{CH}_{3} \mathrm{CN}(10 \mathrm{~mL})$. The precipitate was redissolved in water, washed with $\mathrm{CH}_{2} \mathrm{Cl}_{2}$ thrice, $3 \mathrm{~mL}$ each time. A saturated aqueous solution of $\mathrm{NaCl}$ was added to the solution to give $26 \%$ of 1 , after recrystallisation from a mixture (1:3) water and methanol, mp $>300{ }^{\circ} \mathrm{C} ;{ }^{1} \mathrm{H}$ NMR $\left(\mathrm{D}_{2} \mathrm{O}, 300 \mathrm{MHz}\right) \delta 7.09(8 \mathrm{H}, \mathrm{s})$, $7.81-9.01(32 \mathrm{H}, \mathrm{m}) ;{ }^{13} \mathrm{C}$ NMR $\left(\mathrm{D}_{2} \mathrm{O}, 75 \mathrm{MHz}\right) \delta 72.9,122.2,124.6,125.3,127.7,129.3$, 131.3, 142.7; HRMS (FAB) $\mathrm{m} / z$. Calcd for $\mathrm{C}_{52} \mathrm{H}_{40} \mathrm{~N}_{4} \mathrm{Cl}_{4}$ (M-2Cl): 791.8064 . Found: 791.8072 $(\mathrm{M}-2 \mathrm{Cl})^{+}$.

Preparation of 1-[(anthr-9-yl)methyl]-1'-butyl-4,4'-bipyridinium dibromide (2). The synthesis of the model system 2 was achieved as shown in Scheme 2.

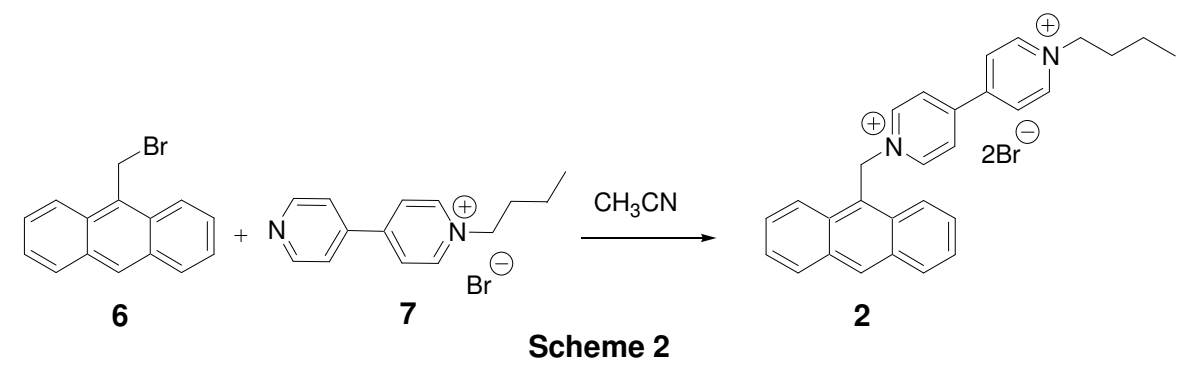

Note: The numbers of the compounds given here correspond to those given in the manuscript.

To a solution of 9-(bromomethyl)anthracene, $6(0.16 \mathrm{~g}, 0.6 \mathrm{mmol})$ in dry acetonitrile (50 mL), 1-butyl-4,4'-bipyridinium bromide, 7 (0.18 g, $0.6 \mathrm{mmol})$ was added and stirred for $12 \mathrm{~h}$ at $25^{\circ} \mathrm{C}$. Precipitated product was filtered, dried and recrystallized from a mixture (6:4) of methanol and ethyl acetate to give $79 \%$ of 2 , mp $289-290{ }^{\circ} \mathrm{C} ;{ }^{1} \mathrm{H} \mathrm{NMR}(300 \mathrm{MHz}$, DMSO- $\left.d_{6}\right) \delta 0.88(3 \mathrm{H}, \mathrm{t}, \mathrm{J}=7.4 \mathrm{~Hz}), 1.28-1.29(2 \mathrm{H}, \mathrm{m}), 1.89-1.91(2 \mathrm{H}, \mathrm{m}), 4.67(2 \mathrm{H}, \mathrm{t}, \mathrm{J}=$ $7.4 \mathrm{~Hz}), 7.08(2 \mathrm{H}, \mathrm{s}), 7.61-9.33(17 \mathrm{H}, \mathrm{m}) ;{ }^{13} \mathrm{C}$ NMR $\left(75 \mathrm{MHz}, \mathrm{DMSO}-d_{6}\right) \delta 13.3,18.7,32.7$, 56.1, 60.5, 121.6, 123.3, 125.8, 126.7, 126.9, 128.4, 129.6, 131.1, 131.4, 131.5, 144.8, 145.7, 148.6, 149.1. HRMS (FAB) $\mathrm{m} / \mathrm{z}$ Calcd for $\mathrm{C}_{29} \mathrm{H}_{28} \mathrm{~N}_{2} \mathrm{Br}_{2}$ (M-Br): 484.4501 . Found: 484.4495 $(\mathrm{M}-\mathrm{Br})^{+}$.

\section{References}

1. Koshiishi, I.; Imanari, T. Anal. Chem. 1997, 69, 216.

2. (a) D. Rehm and A. Weller, Ber. Bunsenges Phys. Chem. 1969, 73, 834. (b) A. Weller, Z. Phys. Chem. 1982, 133, 93.

3. Bernhardt, P. V.; Flanagan, B. M.; Riley, M. J. J. Chem. Soc., Dalton Trans., 1999, 3579.

4. Joseph, J.; Eldho, N. V.; Ramaiah, D. Chem. Eur. J. 2003, 9, 5926.

5. Prayer, C.; Tran-Thi, T.-H.; Pommeret, S.; d'Oliveira, P.; Meynadier, P. Chem. Phys. Lett. 2000, 323, 467.

6. Neelakandan, P. P.; Hariharan, M.; Ramaiah, D. Org. Lett. 2005, 7, 5765. 


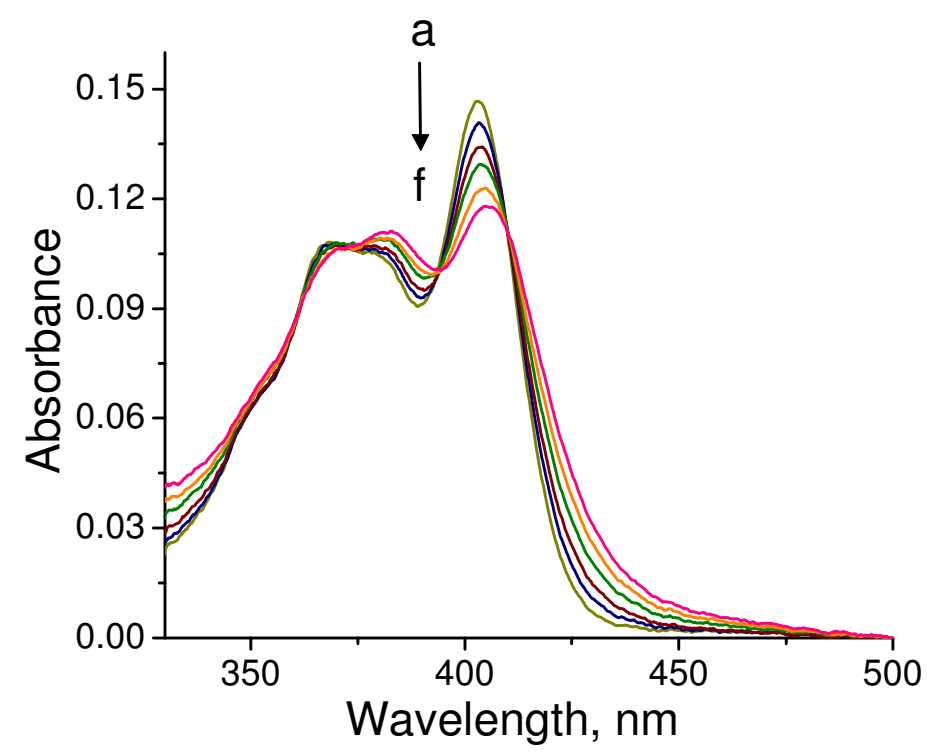

Figure S1. Changes in the absorption spectrum of HPTS $(7 \mu \mathrm{M})$ in $10 \mathrm{mM}$ phosphate buffer with increasing concentration of 1. [1] (a) 0, (b) 1.25, (c) 2.51, (d) 3.78, (e) 5.05 and (f) 6.27 $\mu \mathrm{M}$.

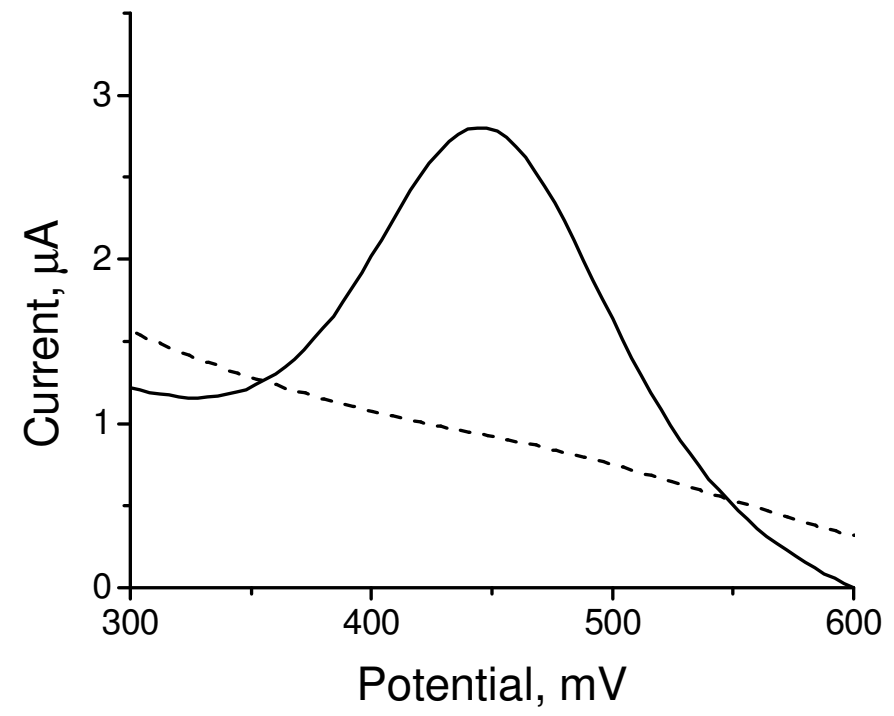

Figure S2. Differential pulse voltammogram of HPTS $(0.24 \mathrm{mM})$ in absence (一) and presence (- -) of the receptor $1(0.33 \mathrm{mM})$. Scan rate $100 \mathrm{mV} / \mathrm{s}$. 


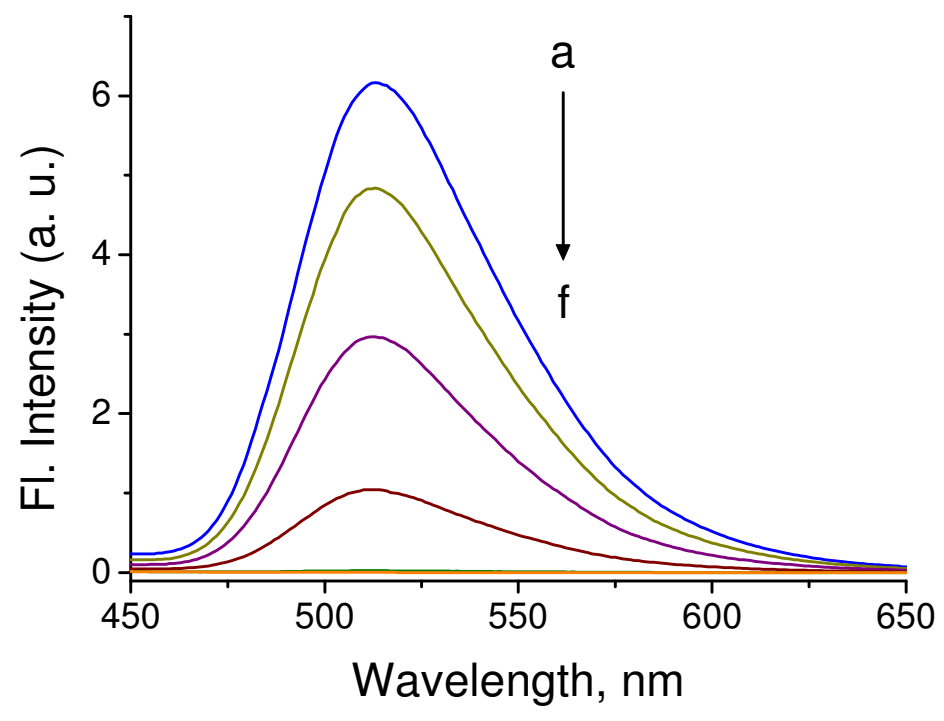

Figure S3. Change in fluorescence spectrum of HPTS $(7 \mu \mathrm{M})$ in $10 \mathrm{mM}$ phosphate buffer containing $2 \mathrm{mM} \mathrm{NaCl}$ with increasing concentration of 1. [1] (a) 0 , (b) 1.25, (c) 2.51, (d) 3.78, (e) 5.05 and (f) $6.27 \mu \mathrm{M}$. Excitation wavelength, $364 \mathrm{~nm}$

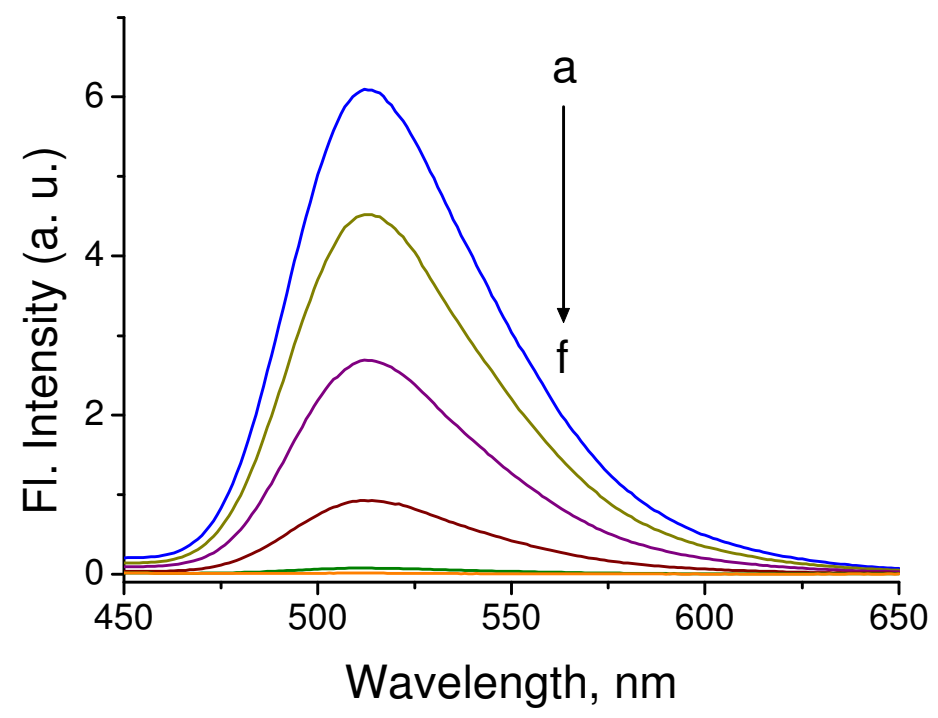

Figure S4. Change in fluorescence spectrum of HPTS $(7 \mu \mathrm{M})$ in $10 \mathrm{mM}$ phosphate buffer containing $50 \mathrm{mM} \mathrm{NaCl}$ with increasing concentration of 1. [1] (a) 0 , (b) 1.25, (c) 2.51, (d) 3.78, (e) 5.05 and (f) $6.27 \mu \mathrm{M}$. Excitation wavelength, $364 \mathrm{~nm}$. 


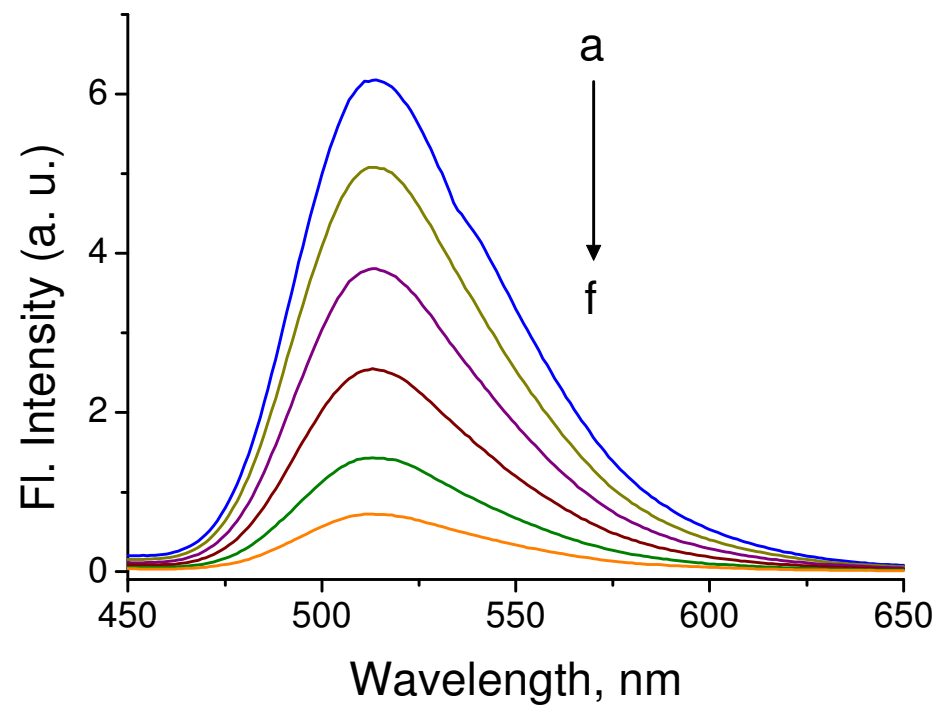

Figure S5. Change in fluorescence spectrum of HPTS $(7 \mu \mathrm{M})$ in $10 \mathrm{mM}$ phosphate buffer containing $500 \mathrm{mM} \mathrm{NaCl}$ with increasing concentration of 1. [1] (a) 0, (b) 1.25, (c) 2.51, (d) 3.78, (e) 5.05 and (f) $6.27 \mu \mathrm{M}$. Excitation wavelength, $364 \mathrm{~nm}$.

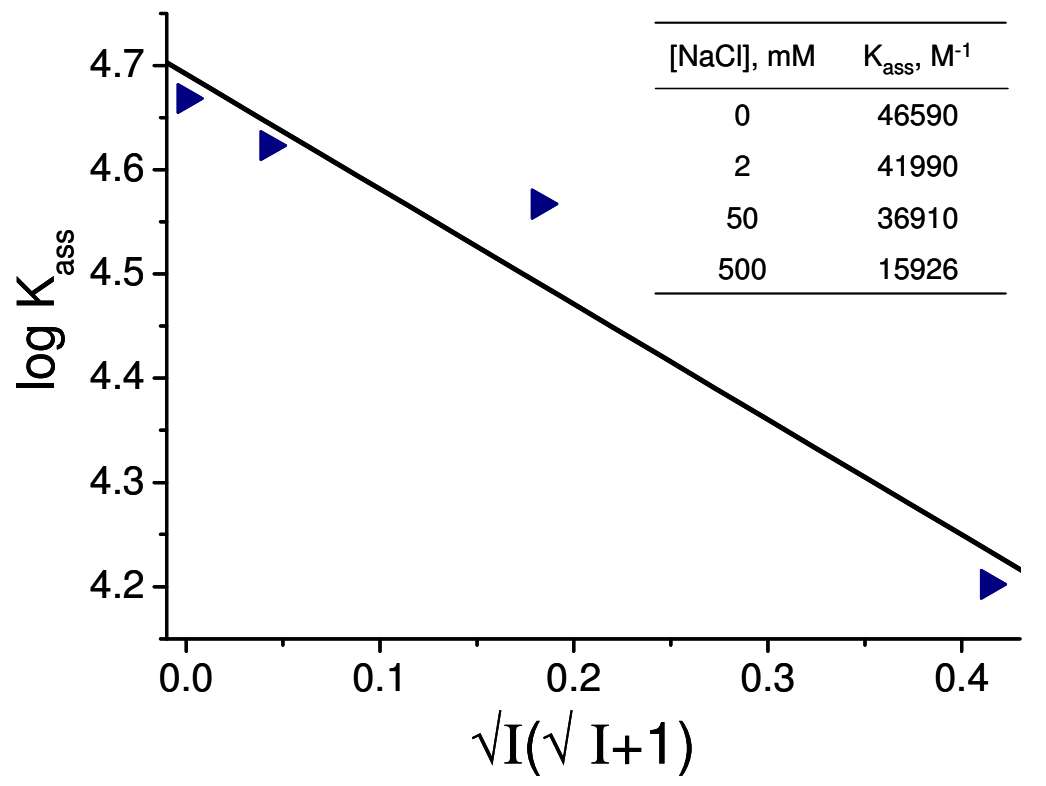

Figure S6. Effect of Debye-Huckel ionic strength function of the medium on association constant $\left(\mathrm{K}_{\text {ass }}\right)$ of the complex [1·HPTS] in $10 \mathrm{mM}$ phosphate buffer (pH 7.4). [NaCl] (a) 0, (b) 2, (c) 50 and (d) $500 \mathrm{mM}$. 


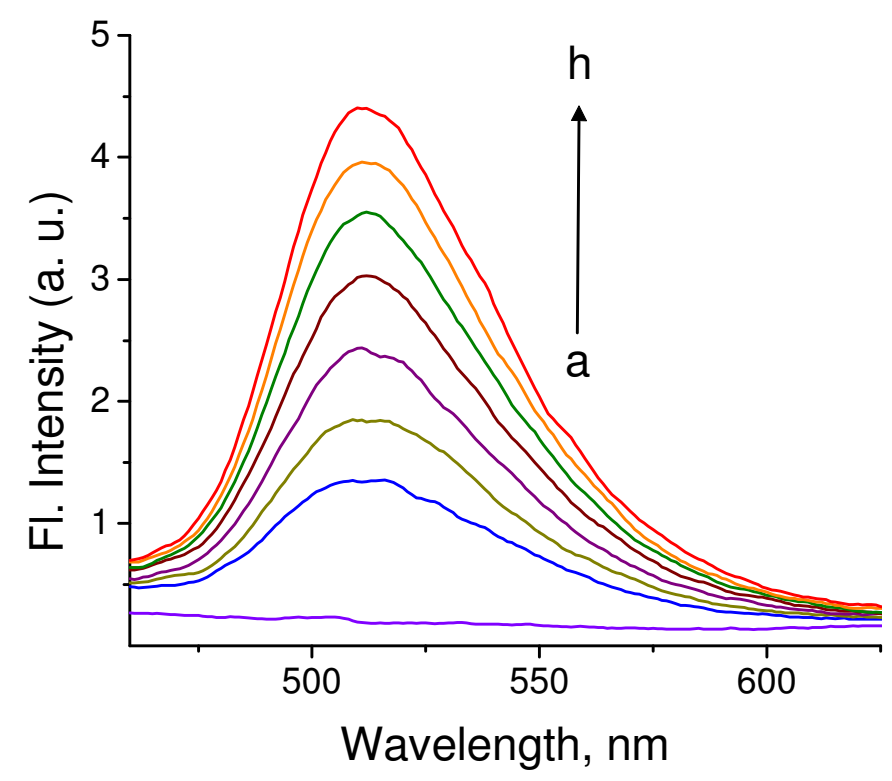

Figure S7. Change in fluorescence spectrum of the complex [1·HPTS] in $10 \mathrm{mM}$ phosphate buffer with increasing concentration of AMP. [AMP] (a) 0, (b) 0.42, (c) 0.62, (d) 0.82, (e) 1.01, (f) 1.21 (g) 1.40 and (h) $1.59 \mathrm{mM}$. Excitation wavelength, $364 \mathrm{~nm}$.

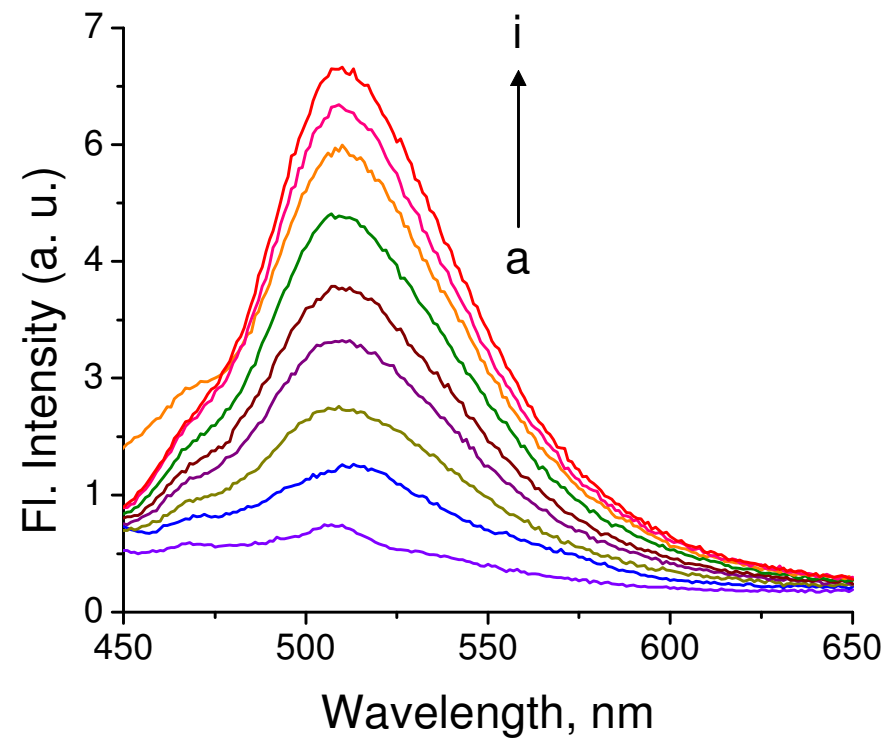

Figure S8. Change in fluorescence spectrum of the complex [1.HPTS] in $10 \mathrm{mM}$ phosphate buffer with increasing concentration of ADP. [ADP] (a) 0, (b) 0.21, (c) 0.42, (d) 0.62, (e) 0.82, (f) 1.01 (g) 1.21 , (h) 1.40 and (i) $1.59 \mathrm{mM}$. Excitation wavelength, $364 \mathrm{~nm}$. 


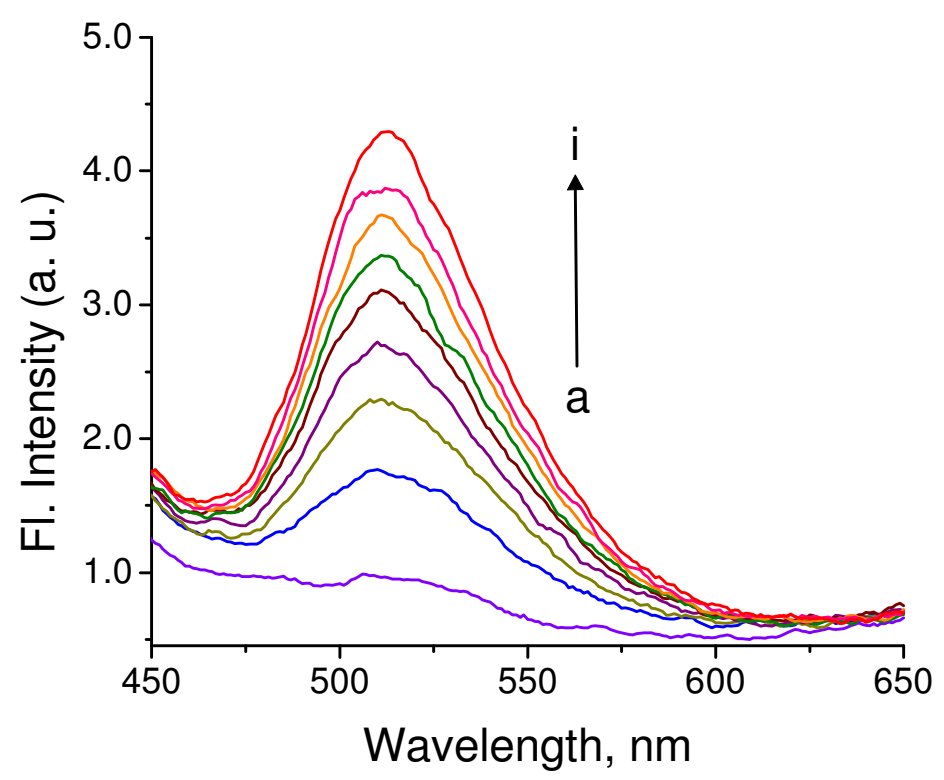

Figure S9. Change in fluorescence spectrum of the complex [1·HPTS] in $10 \mathrm{mM}$ phosphate buffer with increasing concentration of CTP. [CTP] (a) 0, (b) 0.21, (c) 0.42, (d) 0.62, (e) 0.82, (f) $1.01(\mathrm{~g}) 1.21$, (h) 1.4 and (i) $1.59 \mathrm{mM}$. Excitation wavelength, $364 \mathrm{~nm}$.

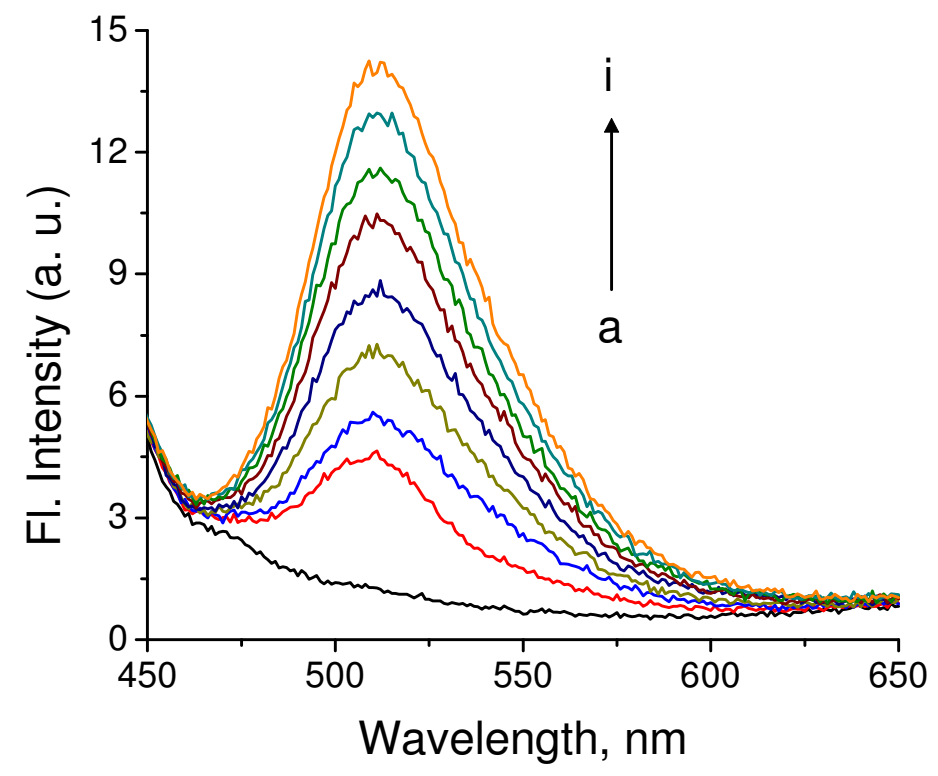

Figure S10. Change in fluorescence spectrum of the complex [1.HPTS] in $10 \mathrm{mM}$ phosphate buffer with increasing concentration of UTP. [UTP] (a) 0, (b) 0.21 , (c) 0.42 , (d) 0.62 , (e) 0.82 , (f) 1.01 (g) 1.21 , (h) 1.4 and (i) $1.59 \mathrm{mM}$. Excitation wavelength, $364 \mathrm{~nm}$. 


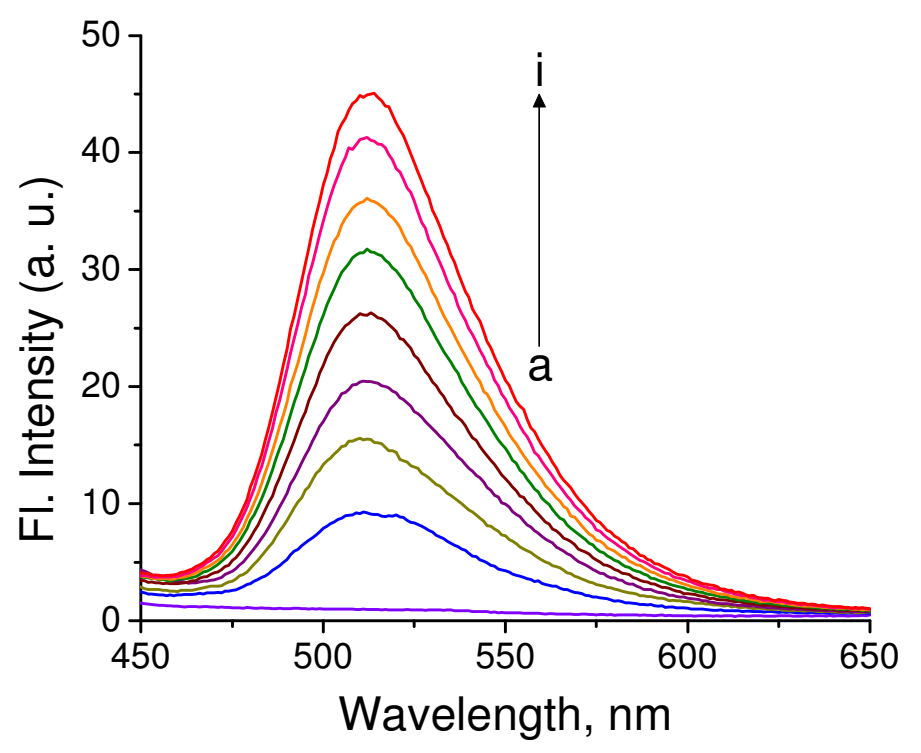

Figure S11. Change in fluorescence spectrum of the complex [1.HPTS] in $10 \mathrm{mM}$ phosphate buffer with increasing concentration of ATP. [ATP] (a) 0, (b) 0.21, (c) 0.42, (d) 0.62, (e) 0.82, (f) 1.01 (g) 1.21 , (h) 1.4 and (i) $1.59 \mathrm{mM}$. Excitation wavelength, $364 \mathrm{~nm}$.

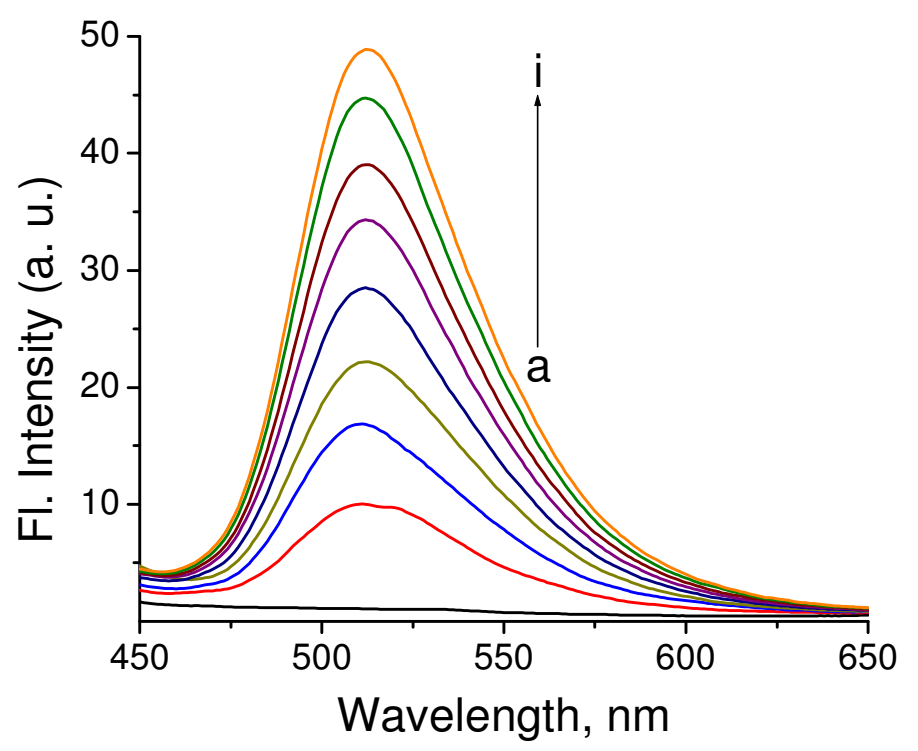

Figure S12. Change in fluorescence spectrum of the complex [1.HPTS] in $10 \mathrm{mM}$ phosphate buffer with increasing concentration of ITP. [ITP] (a) 0, (b) 0.21, (c) 0.42, (d) 0.62, (e) 0.82, (f) 1.01 (g) 1.21 , (h) 1.4 and (i) $1.59 \mathrm{mM}$. Excitation wavelength, $364 \mathrm{~nm}$. 


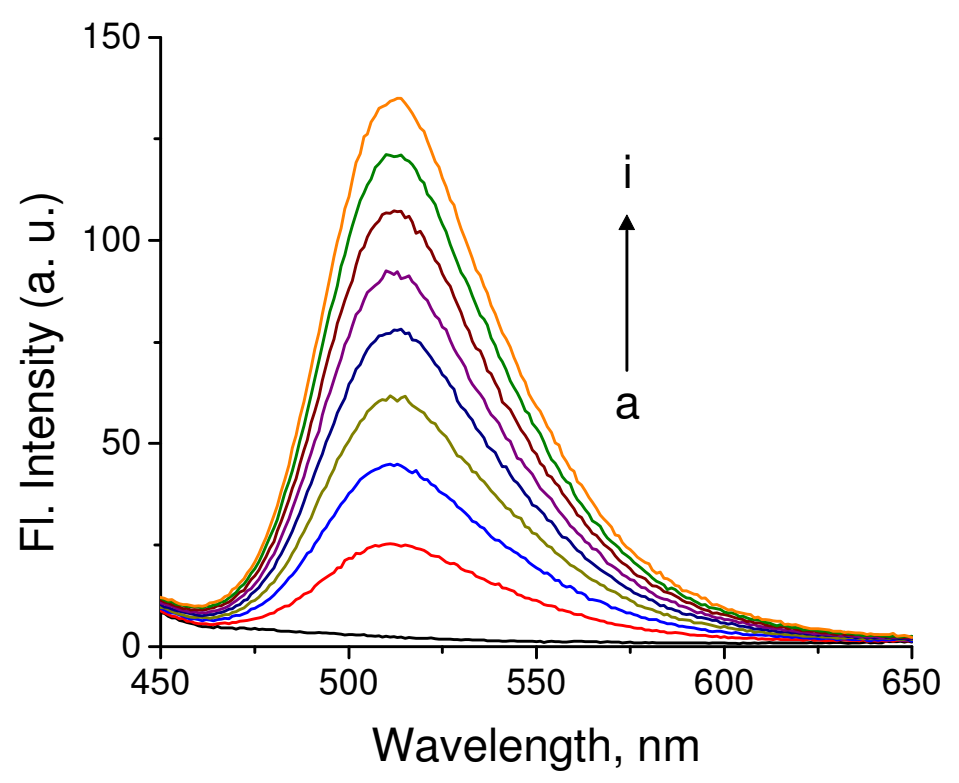

Figure S13. Change in fluorescence spectrum of the complex [1.HPTS] in $10 \mathrm{mM}$ phosphate buffer with increasing concentration of ATP and GTP. [GTP, ATP] (a) 0, (b) 0.21, (c) 0.42, (d) 0.62 , (e) 0.82 , (f) 1.01 (g) 1.21 , (h) 1.4 and (i) $1.59 \mathrm{mM}$. Excitation wavelength, $364 \mathrm{~nm}$.

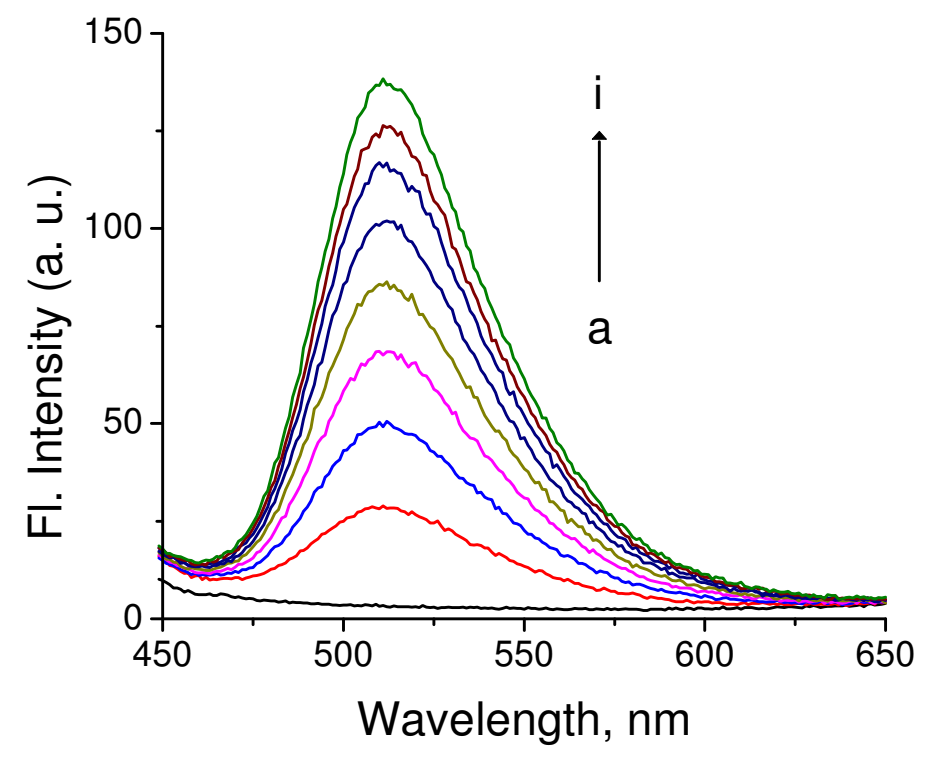

Figure S14. Change in fluorescence spectrum of the complex [1.HPTS] in deproteinized blood serum with increasing concentration of GTP. [GTP] (a) 0, (b) 0.21, (c) 0.42, (d) 0.62, (e) 0.82, (f) $1.01(\mathrm{~g}) 1.21$, (h) 1.4 and (i) $1.59 \mathrm{mM}$. Excitation wavelength, $364 \mathrm{~nm}$. 


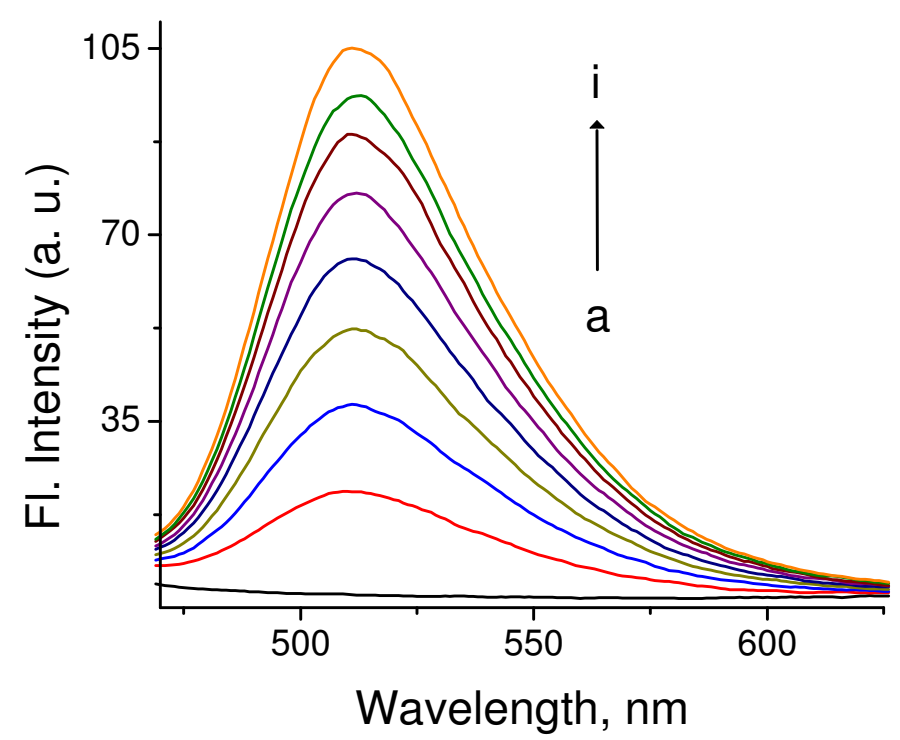

Figure S15. Change in fluorescence spectrum of the complex [1·HPTS] in blood serum (without deproteinization) with increasing concentration of GTP. [GTP] (a) 0, (b) 0.21, (c) 0.42 , (d) 0.62 , (e) 0.82 , (f) 1.01 (g) 1.21 , (h) 1.4 and (i) 1.59 mM. Excitation wavelength, 364 $\mathrm{nm}$. 